\title{
Effect of Compost Rates and Spraying with some Biostimulant Substances on Growth, Yield and Quality of Snap Bean Afifi, S.T. ${ }^{1}$; A. A. A. Shalata ${ }^{2}$ and Rania M. M. Kiera ${ }^{2}$ ${ }^{1}$ Vegetables \& Floriculture Department, Faculty of Agriculture, Mansoura University, Egypt. ${ }^{2}$ Horticulture Research Institute, Agricultural Research Center, Giza, Egypt.
}

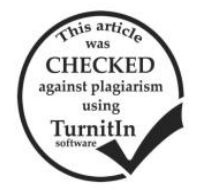
ABSTRACT

Two field experiments were conducted at the private field in El-Zarka City, Damietta Governorate, Egypt, during 2016 and 2017 seasons to evaluate the effects of organic fertilization rates (compost rates) and foliar spraying by some biostimulant substances on yield and its components,growth as well as quality of snap bean (Contender cultivar). A split-plot with three replicates was the experimental design. The vertical-plots to three compost rates i.e. without compost (control treatment), $50 \%$ of the recommended dose ( 2 tons compost/fed) and $100 \%$ of the recommended dose (4 tons compost/fed).The horizontal plots were devoted to four treatments of foliar spraying with some biostimulant substances i.e. foliar spraying with brassinolid at the rate of $10 \mathrm{ppm}$, moringa extract at the rate of 200 ppm, chitosan at the rate of $200 \mathrm{ppm}$ and tap water (control treatment). The most important results can be summarized as follows: The highest values of vegetative growth characters, pod yield and its components as well as quality of snap bean pods were resulted from fertilizing with (4 tons compost/fed) $100 \%$.On the contrary, the lowest values of growth characters, pod yield and its components and chemical composition of snap bean pods were obtained from plants not treated with compost (control treatment). Foliar spraying snap bean plants three times with $200 \mathrm{ppm}$ chitosan exceeded all foliar spraying with some biostimulant substances and resulted the highest values of vegetative growth characters, pod yield and its components as well as quality of snap bean pods. Followed by foliar spraying with brassinolid at the rate of $10 \mathrm{ppm}$ and then moringa extract at the rate of $200 \mathrm{ppm}$. Whereas, the lowest values of vegetative growth characters, pod yield and its components as well as quality of snap bean pods were resulted with control treatment (spraying with tap water).It can be concluded that organic fertilizing with 4 tons compost/fed and foliar spraying three times with chitosan at the rate of 200 ppm folloued by spraying with brassinolid $10 \mathrm{ppm}$ in order to obtain high yield and its components,growth as well as quality of snap bean (Contender cultivar).

Keywords: Snap bean, organic fertilizer, compost, biostimulant substances, chitosan, brassinolid, moringa extract, yield, quality. Growth.

\section{INTRODUCTION}

Snap bean or common bean (Phaseolus vulgaris L), is one of the important legume vegetable crops cultivated in the arid regions for both dry seeds and green pods..It a good source of calories, proteins, dietary fibers, minerals and vitamins for millions of people in both developing and developed countries worldwide. So, it is an important vegetable crop for either exportation or local consumption in Egypt.

Many agricultural practices affect growth, yield and its components as well as quality of snap bean among these firstly chosen high yielding cultivars and using optimum rate of organic fertilization rates (compost rates) and foliar spraying with some biostimulants substances.

Compost is the stable humus-like product resulting from the biological decomposition of organic matter under controlled conditions. It recycles nutrient elements such as nitrogen, sulfur, calcium, phosphorus, carbon, magnesium and trace minerals. These nutrients dont feed the plants directly, but sustain the natural life cycles of the soil by feeding the microorganisms that live there (Marschner, 2012). Chavan et al. (2015) showed that the highest plant height, number of leaves/plant and pods yield of cluster bean were higher with the application of vermicompost, followed by chemical fertilizers and as compared with control field. Islam et al. (2016) reported that bush bean (Phaseolus vulgaris) plants fertilized with vermicompost produced the highest fresh biomass, pod weight, pods number/plant, pod dry weight, pod length, green pod yield and protein content in pods. Rady et al. (2016) showed that addition of compost at a rate of $20 \mathrm{t} /$ ha improved the soil chemical and physical properties besides growth characteristics, pods weight/plant, pod and seed yields of common bean. Otherwise, decreased the concentrations of $\mathrm{Cd}^{2+}$ and $\mathrm{NO}_{3}$ in plant leaves, pods and seeds of common bean. On the other hand, Abou El-Hassan et al. (2017) showed that all treatments of compost and vermicompost without mineral fertilizers decreased all vegetative characters, early and total yield of green beans plants and nitrate content of green bean pods. Bucagu et al. (2017) found that application of organic fertilizers significantly increased leaf area, plant height, number of leaves, pods, weight of pods and total pod yield of snap bean. Changa et al. (2017) indicated that compost addition up to $20 \%$ had a positive influence on plant emergence and plant growth index (shoot height, stem diameter, leaf area, root dry weight and plant biomass) of green bean. Fouda et al. (2017) showed that the best treatment that produced the highest values of vegetative growth parameter, pod length, pod diameter and yield of bean as well as quality parameters of bean plant was NPK $100 \%+$ compost, compared to control. Thiyageshwari et al. (2018) reported that an increase in seed yield of blackgram (16-17\%) over $100 \%$ recommended dose of fertilizer (RDF) was obtained from the integrated application of composted rice husk $(\mathrm{CRH})$ at $5 \mathrm{t} / \mathrm{ha}$ with $50 \% \mathrm{RDF}$ and biofertilizers.

Moringa oleifera Lam. (miracle tree) from Moringaceae family is native to the sub-Hamaylian tract of India and Pakistan (Shahzad et al., 2013). Due to its high nutritional value it has many benefits and wide range of uses. The moringa plant is contains many nutrients such as, vitamins, proteins, minerals, antioxidants and phytonutrients. Fresh moringa leaves have been shown to have high zeatin content, where zeatin is one form of the most common forms of naturally occurring cytokinin in plants. Emongor (2015) showed that moringa leaf extract applied at 11,20, 33 and 50\% concentration to snap bean plants at 10 days after emergence significantly increased vegetative growth, leaf chlorophyll content, plant dry matter (shoot and root) as well as yield components and fresh pod yield. Zaki and Rady (2015) found that foliar spraying or seed soaking by Moringa oleifera leaf extract significantly increased growth characters, yields of green 
pods and dry seeds and physio-chemical attributes of common bean.

Chitosan is a natural linear polysaccharide composed of polysaccharide called 2-Amino-2-deoxybeta-Dglucosasmine. Chitosan can be extracted from the marine crustacean like shrimps, cramp, and pinfish or from the exoskeletons of most insects under the name of chitin which can be transformed into chitosan by extracting the acetyl group and turn it into amino. Sheikha and Al-Malki (2011) indicated that chitosan enhanced bean shoot and root lengths, fresh and dry weights of shoots, root and leaf area as well as the level of chlorophylls. Abu-Muriefah (2013) stated that foliar application with chitosan $(200 \mathrm{mg} / \mathrm{L})$ increased total yield per plant, plant growth, nitrogen, phosphorous, potassium, protein and carbohydrates of common bean under stressed or non-stressed conditions as compared to chitosan untreated plants.

Brassinolide, a novel plant growth promoting steroidal lactone, was first isolated from rape (Brassica napus L.) pollen and was found to exhibit unique plant growth responses in several test systems (Gregory and Mandava, 1982). Brassinolide play various physiological roles in growth-promoting activity and other developmental processes like seed germination, photosynthesis (Sairam, 1994), enhanced levels of nucleic acids, soluble proteins and carbohydrates (Kalinich et al., 1985) and stress tolerance. El-Bassiony et al. (2012) reported that spraying snap bean plants with brassinosteroids (BRs) at a concentration of 25 and $50 \mathrm{ppm}$ increased vegetative growth, total yield and quality of pods. Matwa et al. (2017) found that the best treatment that significantly increased number of pods/plant, pod weight/plant, pod length, harvest index and biological yield was foliar spraying green gram plants Brassinolide at the rate of $0.25 \mathrm{ppm}$.

Therefore, this study was conducted to explain the effects of organic fertilization rates (compost rates) and foliar spraying on yield and its components, growth and quality of snap bean (Contender cultivar).

\section{MATERIALS AND METHODS}

Two field experiments were conducted at the private field in El-Zarka City, Damietta Governorate, Egypt, during 2016 and 2017 seasons. The aim of these experiments was to evaluate the effects of organic fertilization rates (compost rates) with foliar spraying by some biostimulant substances on yield and its components, growth and quality of snap bean (Contender cultivar).

A split-plot with three replicates was the experimental design. The vertical-plots were devoted to three compost rates i.e. without compost (control treatment), $50 \%$ of the recommended dose (2 tons compost $/$ fed) and $100 \%$ of the recommended dose (4 tons compost/fed). The compost was added in the experimental units as the aforementioned rates on soil surface and then turned over via hack. Analysis of used compost it has been obtained from aprivate company was shown (Table 1).

The horizontal plots were devoted to four treatments of foliar spraying with some biostimulant substances i.e. Brassinolid at $10 \mathrm{ppm}$, moringa extract at $200 \mathrm{ppm}$, chitosan at $200 \mathrm{ppm}$ and tap water (control treatment). By hand sprayer the foliar solution was conducted (for experimental plots) until saturation point three times, after 10 days from sowing and repeated each 10 days interval.

Table 1. Chemical analysis of compost used in two seasons.

\begin{tabular}{lc}
\hline Analysis & Result \\
\hline Moisture (\%) & 25.00 \\
Density (g/L) & 750 \\
Ash (\%) & 68.00 \\
OM (\%) & 32.00 \\
C/N ratio & $16.87 / 1$ \\
C (\%) & 18.56 \\
N (\%) & 1.10 \\
P (\%) & 0.40 \\
pH & 7.50 \\
EC m.mohs/cm & 3.60 \\
Mg (\%) & 0.20 \\
\hline
\end{tabular}

The experimental plot area was $10.5 \mathrm{~m}^{2}$, which contained 3 rows, $0.7 \mathrm{~m}$ width and each $5 \mathrm{~m}$ long.

The experimental field was well prepared and divided into the experimental units with dimensions as previously mentioned. was applied Calcium superphosphate $\left(15.5 \% \mathrm{P}_{2} \mathrm{O}_{5}\right)$ during soil preparation at the rate of $60 \mathrm{~kg} \mathrm{P}_{2} \mathrm{O}_{5} /$ fed.

Snap bean cv. Contender seeds were sown on two side of the ridge at hills in the moderately moist soil (3-4 seeds/hill) in the last week of February at first and second season, respectively and after germination and before the first irrigation thinned to two plants/hill. All plants were fertilized with recommended doses of nitrogen and potassium fertilizer according to recommendation of Ministry of Agriculture.

According to the instructions laid down by the Ministry of Agriculture, Egypt all the other cultural practices for snap bean commercial production were used .

The recorded data

\section{1- Vegetative growth characters:}

Were taken Representative samples of 5 plants as randomly at 55 days after sowing from each plot to estimate the following characters:

- Number of branches

- Plant height (cm).

- Number of leaves.

- Stem diameter ( $\mathrm{mm})$.

- First node height $(\mathrm{cm})$.

- Plant fresh weight (g).

- Plant dry weight (g): For a constant weight chosen five plants were dried at $70^{\circ} \mathrm{C}$ and then average dry weight was calculated per plant in grams.

- Plant leaves area $\left(\mathrm{cm}^{2}\right)$ : from each fresh leaves were taken Random samples of chosen plants to give 10 disks/plant (disk area was $7.07 \mathrm{~cm}^{2}$ ) and weighted till constant weight after dried at $70^{\circ} \mathrm{C}$. as offered by Koller (1972) Plant leaf area was calculated.

Leaves ory wejght $x$ (No.of disks $\times$ disks area)

2- Pod yield and its components

$$
\text { Disks dry weight }
$$

At the proper maturing stage green pods of each plot were harvested, counted and weight in each harvest and the following parameters were recorded. 
- Pod diameter (mm).

- Numbar of pods /plant

- Pod weight (g).

- Pod length (cm).

- Total pod yield ( $\mathrm{t} / \mathrm{fed})$. Whole green pods of each plot were harvested and weighted $(\mathrm{kg})$, then converted to ton per feddan.

\section{3- Quality characters of pods}

Representative samples (each $200 \mathrm{~g}$ ) from dried snap bean pods was taken at harvest of each treatment, As described by Hesse (1971) ground and wet digested as to determine the following parameters:

- Total soluble solids content (TSS \%): To determine the total soluble solids hand using Refract-meter ten random samples from snap bean pods were taken.

- Crude protein content (CP \%): Protein was determined according to (A. O. A. C., 2000).

- Crude fibers content (CF \%): The usual method published by A.O.A.C. (2007) was used for determination of crude fibers content in snap bean pods.

According to the technique of analysis of variance(ANOVA) All obtained data were statistically analyzed for the split plot design as offered by Gomez and Gomez (1984) by using "COSTAT" computer software package. Least significant of difference (LSD) method was used to test the differences between treatment means at 5 $\%$ level of probability as offered by Snedecor and Cochran (1980).

\section{RESULTS AND DISCUSSION}

\section{1- Effect of compost rates}

Regarding the effect of compost rates on vegetative growth characteristics of snap bean i.e. plant height, number of branches, number of leaves, stem diameter, first node height, plant dry and fresh weights and plant leaves, the results in Table 2 apparently cleared that there were significant effects in two seasons. It could be seen that increasing compost rates from zero (control treatment) to $50 \%$ (2 tons compost/fed) and $100 \%$ (4 tons compost/fed) , lead to significant increase in all vegetative growth characteristics of snap bean in both growing seasons. Therefore, the highest values of vegetative growth characteristics were resulted from fertilizing snap bean plants with (4 tons compost/fed) $100 \%$ in two seasons. On the other side,the lowest values of vegetative growth characteristics were obtained from snap bean plants untreated with compost (control treatment) in two seasons. Ascribed this increase in vegetative growth characteristics of snap bean allied with increasing compost rates to mineralization of organic nitrogen contained in compost that gradually released nitrogen during the growing season, the role of compost in reducing the soil $\mathrm{pH}$ especially in the rhizosphare, thereby, increases the availability of most essential macro and micro nutrients, positive role of nitrogen secreted from compost on division and elongation of stem meristematic tissues and plant photosynthesis assimilates, and consequently enhance establishment and growth of snap bean. These results are in good compatible with those recorded by Abou El-Hassan et al. (2017), Bucagu et al. (2017) and Changa et al. (2017).
Pod yield and its components of snap bean were significantly increased by increasing compost rates from zero (control treatment) to $50 \%$ (2 tons compost/fed) and $100 \%$ (4 tons compost/fed) in the two growing seasons (Table 3). The highest values of pod yield and its components of snap bean were resulted from fertilizing snap bean plants with 4 tons compost/fed (100\%) in both seasons. Fertilizing snap bean plants with 2 tons compost/fed $(50 \%)$ came in the second rank after fertilizing with $100 \%$ in both seasons. Untreated snap bean plants with compost (control treatment) gave the lowest values of pod yield and its components in both seasons. These results ascribed to the role of compost in improving vegetative growth, besides compost is a source of slow release nutrients, and contains a number of macro and micronutrients, and consequently high accumulation of dry matter which resulted increase pod yield per unit area and increase all yield components. These results are harmony with those of Abou El-Hassan et al. (2017) and Bucagu et al. (2017).

As regards the effect of compost rates on chemical composition of snap bean pods, there was significant effect of increasing compost rates on the chemical composition of snap bean pods in the two growing seasons of this study (Table 4). In general, increase the compost rates from 0 to 2 and 4 tons compost/fed was led to significant increase in chemical composition of snap bean pods in two growing seasons. Where, the highest values of chemical composition of snap bean pods were resulted from fertilizing snap bean plants with 4 tons compost/fed (100 $\%$ ) in both seasons. Fertilizing snap bean plants with 2 tons compost/fed $(50 \%)$ ranked secondly after fertilizing with $100 \%$ in both seasons. Whereas, untreated with compost (control treatment) produced the lowest percentages of chemical composition of snap bean pods in both seasons. There was contrary tendency Concerning crude fiber percentage, The highest values were resulted from snap bean plants without compost and the lowest values were resulted from snap bean plants fertilized with 4 tons compost/fed in both seasons. Such increments detected in chemical composition of snap bean pods with increasing compost rates may be effective roles in improving dry matter accumulation in leaves, growth and yield attributes. These results are harmony with those of Abou El-Hassan et al. (2017).

\section{2- Effect of spraying with some biostimulant substances}

It is obvious from the data in Table 2 foliar spraying with some biostimulant substances i.e. foliar spraying with brassinolid at $10 \mathrm{ppm}$, moringa extract at $200 \mathrm{ppm}$, chitosan at $200 \mathrm{ppm}$ and tap water (control treatment) significantly affected vegetative growth characteristics of snap bean in both seasons. Foliar spraying snap bean plants with chitosan 200 ppm produced the highest values of vegetative growth characteristics of snap bean in both seasons. Followed by foliar spraying with brassinolid $10 \mathrm{ppm}$ and then moringa extract $200 \mathrm{ppm}$ in two seasons. On the contrary, the lowest values of vegetative growth characteristics were resulted from (spraying with tap water) control treatment in both seasons. The characteristics of vegetable growth of snap bean increased by three times foliar spraying with biostimulant substances may be due to the role of plant growth 
biostimulants in regulating a some of physiological processes such as photosynthesis, growth, ethylene production and nitrate metabolism. Besides, brassinolide plays various physiological roles in growth-promoting activity and other developmental processes like seed germination, photosynthesis, enhanced levels of nucleic acids, soluble proteins and carbohydrates and stress tolerance. Also, application of chitosan increased key enzymes activities of nitrogen metabolism (nitrate reductase, glutamine synthetase and protease) and improved the transportation of nitrogen in the functional leaves which enhanced plant growth and development. Also, the role of fresh moringa leaves extract, which have been shown to have high zeatin content, where one of the most common forms of naturally occurring cytokinin in plants is zeatin, and improved membranes stability, enhanced antioxidant levels and activated plant defense system, which reflected on increases in vegetative growth characteristics of snap bean. These results are harmony with those reported by Abu-Muriefah (2013) and Emongor (2015).

Table 2. Plant height, number of branches, number of leaves, stem diameter, first node height, plant fresh and dry weights and plant leaves area as affected by compost rates and foliar spraying with some biostimulant substances during 2016 and 2017 seasons.

\begin{tabular}{|c|c|c|c|c|c|c|c|c|c|c|c|c|c|c|c|}
\hline \multirow[t]{2}{*}{ Treatments } & \multicolumn{2}{|c|}{$\begin{array}{l}\text { Plant } \\
\text { height } \\
(\mathrm{cm})\end{array}$} & \multicolumn{2}{|c|}{$\begin{array}{l}\text { No. of } \\
\text { branches/ } \\
\text { plant }\end{array}$} & \multicolumn{2}{|c|}{$\begin{array}{c}\text { No. } \\
\text { of } \\
\text { leaves/plant }\end{array}$} & \multicolumn{2}{|c|}{$\begin{array}{c}\text { Stem } \\
\text { Diameter } \\
(\mathbf{m m})\end{array}$} & \multicolumn{2}{|c|}{$\begin{array}{l}\text { First } \\
\text { Node } \\
\text { (cm) }\end{array}$} & \multicolumn{2}{|c|}{$\begin{array}{l}\text { Plant fresh } \\
\text { weight } \\
\text { (g) }\end{array}$} & \multicolumn{2}{|c|}{$\begin{array}{l}\text { Plant dry } \\
\text { weight } \\
\text { (g) }\end{array}$} & \multirow[t]{2}{*}{$\begin{array}{c}\text { Plant leaves } \\
\begin{array}{l}\text { area } \\
\left(\mathrm{cm}^{2}\right)\end{array}\end{array}$} \\
\hline & 2016 & 2017 & 2016 & 2017 & 2016 & 2017 & 2016 & 2017 & 2016 & 2017 & 2016 & 2017 & 2016 & 2017 & \\
\hline \multicolumn{16}{|l|}{ omp } \\
\hline & & & & & & & & & & & & & & & \\
\hline & & & & & & & & & & & & & & & \\
\hline & & & 31 & & & & 24 & & & & & & & & \\
\hline LDD at 570 & & 0.71 & 0.29 & 0.36 & & & 0.33 & & & & & & & & \\
\hline \multicolumn{16}{|c|}{ Foliar spraying with some biostimulant substances: } \\
\hline & & & & & 13.40 & & 5.20 & & & & & & & & \\
\hline & & & & & 3.08 & & 5.21 & & 23 & & & & & & \\
\hline & .60 & & 5.34 & 6.2 & 13.51 & 4 & 5.31 & & 4.50 & & & & 46. & & 47608. \\
\hline & .01 & 31.35 & 4.22 & 4.2 & 11.77 & 11.95 & 4.23 & & 3.84 & 4.53 & 161 & 194.1 & 36.99 & 46.16 & 6120.96373 .7 \\
\hline SD at $5 \%$ & 0.39 & 0.31 & 0.25 & 0.26 & 0.39 & 0.41 & 0.40 & 0.48 & 0.217 & 0.383 & 2.1 & 2.3 & 0.61 & 0.65 & 111.9220 .0 \\
\hline
\end{tabular}

The statistical analysis of the calculated data on pod yield and its components make sure these studied foliar spraying by some biostimulant substances significantly affected these pod yield and its components of snap bean in both seasons (Table 3). It is clearly seen that, the highest values of pod yield and its components Caused by foliar spraying with chitosan in both seasons This treatment followed by foliar spraying with brassinolid $10 \mathrm{ppm}$, and then moringa extract $200 \mathrm{ppm}$ in both seasons. Whereas, the lowest values of pod yield and its components were resulted from (spraying with tap water) control treatment in both seasons. The desirable effect of foliar spraying snap bean plants with some biostimulant substances on yield and its components might have been due to its effective role in improving snap bean growth, stimulated the building of metabolic products which translocated to seeds and more dry matter accumulation. In addition to, the significant effects of biostimulants such as chitosan, brassinolid and moringa extract as mentioned formerly in improving plant growth characteristics such as number of branches, plant height, stem diameter, number of leaves, first node height, plant fresh and dry weights and plant leaves area, And therefore increasing pod yield and its components. It results are in good compatible with those recorded by Abu-Muriefah (2013), Emongor (2015) and Matwa et al. (2017).

Table 3. Pod length, pod diameter, pod weight, number of pods/plant and total pod yield/fed as affected by seasons rates of compost and foliar spraying with some biostimulant substances during 2016 and 2017 seasons.

\begin{tabular}{|c|c|c|c|c|c|c|c|c|c|c|}
\hline \multirow[t]{2}{*}{ Treatments } & \multicolumn{2}{|c|}{$\begin{array}{c}\text { Pod length } \\
(\mathrm{cm})\end{array}$} & \multicolumn{2}{|c|}{$\begin{array}{c}\text { Pod diameter } \\
(\mathrm{mm})\end{array}$} & \multicolumn{2}{|c|}{$\begin{array}{c}\text { Pod weight } \\
\text { (g) }\end{array}$} & \multicolumn{2}{|c|}{$\begin{array}{c}\text { No. of pods/ } \\
\text { plant }\end{array}$} & \multicolumn{2}{|c|}{$\begin{array}{c}\text { Total pod yield } \\
\text { (t/fed) }\end{array}$} \\
\hline & 2016 & 2017 & 2016 & 2017 & 2016 & 2017 & 2016 & 2017 & 2016 & 2017 \\
\hline \multicolumn{11}{|l|}{ Compost rates: } \\
\hline Without compost & 11.18 & 12.53 & 6.83 & 7.17 & 4.38 & 5.56 & 21.61 & 22.42 & 5.48 & 5.65 \\
\hline $50 \%$ compost & 11.77 & 12.73 & 7.15 & 7.56 & 4.74 & 5.82 & 28.36 & 28.66 & 6.05 & 6.30 \\
\hline $100 \%$ compost & 12.43 & 13.03 & 7.78 & 7.84 & 4.92 & 6.04 & 36.13 & 36.41 & 6.63 & 7.09 \\
\hline LSD at $5 \%$ & 0.80 & 0.26 & 0.25 & 0.52 & 0.33 & 0.19 & 0.80 & 0.28 & 0.53 & 0.32 \\
\hline \multicolumn{11}{|c|}{ Foliar spraying with some biostimulant substances: } \\
\hline Brassinolid(10 ppm) & 12.25 & 13.00 & 7.48 & 7.69 & 4.61 & 5.96 & 32.11 & 33.05 & 6.41 & 6.57 \\
\hline Moringa (200 ppm) & 11.87 & 12.90 & 7.19 & 7.81 & 4.76 & 5.79 & 29.26 & 29.55 & 6.12 & 6.31 \\
\hline Chitosan (200 ppm) & 12.40 & 13.10 & 7.57 & 7.84 & 5.14 & 6.06 & 36.51 & 36.83 & 6.60 & 7.16 \\
\hline Control treatment & 10.65 & 12.04 & 6.77 & 6.76 & 4.21 & 5.42 & 16.92 & 17.22 & 5.11 & 5.31 \\
\hline LSD at $5 \%$ & 0.42 & 0.46 & 0.33 & 0.35 & 0.24 & 0.25 & 0.52 & 0.32 & 0.31 & 0.24 \\
\hline
\end{tabular}

The statistical analysis of data of chemical composition of snap bean pods these studied foliar spraying with some biostimulant substances showed significant effects on the chemical composition of snap bean pods in both seasons. We find that, the highest values of chemical composition of snap bean pods were formed 
from foliar spraying plants with chitosan $200 \mathrm{ppm}$ in both seasons (Tables 4). Foliar spraying snap bean plants with brassinolid $10 \mathrm{ppm}$ came after chitosan treatment in the second rank in the two growing seasons. While, the minimum percentages of chemical composition of snap bean pods were obtained when snap bean plants untreated with compost (control treatment) in both seasons. Regarding crude fiber percentages in snap bean pod, it had opposing propensity where the snap bean plants spraying with tap water (control treatment) were resulted highest values and the snap bean plants sprayed with chitosan were resulted lowest values in both seasons. Attributed these results to the enhanced effects of chitosan as a high molecular natural polymer, bioactive agent, nontoxic, fungicidal effects. Brassinolide plays various physiological roles in growth-promoting activity and other developmental processes like seed germination, photosynthesis, enhanced levels of nucleic acids, soluble proteins and carbohydrates and stress tolerance. Also, the role of moringa leaves extract, which has an important benefits and wide range of uses due to its loaded with nutrients such as vitamins, antioxidants, proteins minerals, and phytonutrients. accordingly increasing chemical composition of snap bean pods. These results are in good compatible with those recorded by El-Bassiony et al. (2012), Abu-Muriefah (2013) and Zaki and Rady (2015).

Table 4. Total soluble solids (TSS), crude protein (CP) and crude fiber (CF) percentages in snap bean pods as affected by compost rates and foliar spraying with some biostimulant substances during 2016 and 2017 seasons.

\begin{tabular}{lcccccc}
\hline \multirow{2}{*}{ Treatments } & \multicolumn{2}{c}{ TSS(\%) } & \multicolumn{2}{c}{ CP(\%) } & \multicolumn{2}{c}{ CF(\%) } \\
\cline { 2 - 7 } & $\mathbf{2 0 1 6}$ & $\mathbf{2 0 1 7}$ & $\mathbf{2 0 1 6}$ & $\mathbf{2 0 1 7}$ & $\mathbf{2 0 1 6}$ & $\mathbf{2 0 1 7}$ \\
\hline Compost rates: & & & & & & \\
Without compost & 6.66 & 6.25 & 20.39 & 22.70 & 8.04 & 8.68 \\
50\% compost & 7.33 & 6.58 & 20.96 & 23.60 & 7.39 & 8.03 \\
100 \% compost & 8.08 & 7.41 & 21.64 & 24.18 & 6.62 & 7.93 \\
\hline LSD at 5\% & 0.68 & 0.46 & 0.12 & 0.11 & 0.43 & 0.02 \\
\hline Foliar spraying with some biostimulant substances: & 7.65 & 21.35 & 24.28 & 6.99 & 7.87 \\
Brassinolid(10 ppm) & 7.11 & 7.55 & 21.07 & 24.19 & 7.03 & 7.86 \\
Moringa (200 ppm) & 6.77 & 7.67 & 21.77 & 24.73 & 6.89 & 7.58 \\
Chitosan (200 ppm) & 7.22 & 5.88 & 19.79 & 20.78 & 8.49 & 9.52 \\
Control treatment & 6.55 & 0.37 & 0.70 & 0.05 & 0.69 & 0.02 \\
\hline LSD at 5 \% & 0.44 & & & & & \\
\hline
\end{tabular}

\section{Effect of interaction}

The interaction between the compost rates and foliar spraying with some biostimulant substances have The stimulative effect on pod yield and its components, vegetative growth characteristics and chemical composition of snap bean pods in both seasons (Tables 5, 6 and 7).

The highest values from pod yield and its components, vegetative growth characteristics and chemical composition of snap bean pods were resulted from fertilizing snap bean plants with 4 tons compost/fed and foliar spraying three times with chitosan in both seasons (Tables 5, 6 and 7). The fertilizing snap bean plants with 4 tons compost/fed and foliar spraying with

brassinolid $10 \mathrm{ppm}$ was second best interaction treatment in both seasons. While, control treatment of all studied factors (Without compost and spraying with tap water) gaved the lowest values of pod yield and its components, vegetative growth characteristics and chemical composition of snap bean pods in both seasons. As regards crude fiber percentage in snap bean pods, it had conflicting inclination where the highest values were resulted from control treatment of both studied factors and the lowest values were resulted from fertilizing snap bean plants with 4 tons compost/fed and foliar spraying with chitosan 200 ppm in tow seasons.

Table 5. Plant height, number of branches, number of leaves and stem diameter as affected by the interaction between compost rates and foliar spraying with some biostimulant substances during seasons 2016 and 2017.

\begin{tabular}{|c|c|c|c|c|c|c|c|c|c|c|c|c|c|c|c|}
\hline \multirow[t]{2}{*}{ Treatments } & \multicolumn{2}{|c|}{$\begin{array}{l}\text { Plant height } \\
\text { (cm) }\end{array}$} & \multicolumn{2}{|c|}{$\begin{array}{c}\text { No. of } \\
\text { branches/plant }\end{array}$} & \multicolumn{2}{|c|}{$\begin{array}{c}\text { No. of } \\
\text { leaves/plant }\end{array}$} & \multicolumn{2}{|c|}{$\begin{array}{c}\text { Stem Diameter } \\
(\mathrm{mm})\end{array}$} & \multicolumn{2}{|c|}{$\begin{array}{c}\text { First } \\
\text { node(cm) }\end{array}$} & \multicolumn{2}{|c|}{$\begin{array}{l}\text { Plant fresh } \\
\text { weight (g) }\end{array}$} & \multicolumn{2}{|c|}{$\begin{array}{l}\text { Plant dry } \\
\text { weight (g) }\end{array}$} & \multirow{2}{*}{$\begin{array}{c}\begin{array}{c}\text { Plant leaves } \\
\text { area }\left(\mathrm{cm}^{2}\right)\end{array} \\
2016 \quad 2017\end{array}$} \\
\hline & 2016 & 2017 & 2016 & 2017 & 2016 & 2017 & 2016 & 2017 & 2016 & 2017 & 2016 & 2017 & 2016 & 2017 & \\
\hline \multicolumn{16}{|l|}{ Compost rates: } \\
\hline & & & 4.93 & 520 & 12.33 & 12.93 & & & 4.10 & & & 220.8 & 41.00 & & \\
\hline At Moring & & & & & & & & & & & & & & & \\
\hline compost & & & & & & & & & & & & & & & \\
\hline & & & .00 & & 11.46 & & & & 56 & & & & 63 & & \\
\hline & & & & & 13.46 & & & & & & & & & & \\
\hline $50 \%$ & & & 10 & & 13.20 & & & & & & & & 45. & & \\
\hline compost Chit & 32. & & 20 & & 13.66 & 14.33 & & & & & & & 46. & & \\
\hline & 29. & & 30 & & 11.86 & 12.00 & 4.3 & & 3.93 & & & 19 & 38.87 & & 63 \\
\hline & 33.8 & & 5.60 & 700 & 13.80 & 14.66 & & & & & 204.0 & 284.7 & 47.26 & 67.91 & 57916.2 \\
\hline $100 \% \quad \mathrm{~N}$ & 32.26 & 36.3 & 5.46 & 6.53 & 13.73 & 14.46 & 5.4 & & 4. & 5.6 & 187.5 & 266.6 & 46.89 & 65.47 & 67812.2 \\
\hline compost Chit & 34. & & 5.83 & & 13.80 & 14.86 & 5.5 & & 4. & & 212 & 301.3 & 51.85 & 69.24 & 7.97940 .4 \\
\hline & 29.8 & 32. & 4.36 & 4.5 & 12.00 & 12.20 & 4.4 & & 3.93 & 4.7 & 164.9 & 202.4 & 39.47 & 50.24 & 6676.06756 .1 \\
\hline $\mathrm{LSD}$ at $5 \%$ & 0.67 & 0.53 & 0.68 & 0.82 & 1.21 & 0.99 & 0.69 & 0.83 & 0.38 & 0.66 & 3.64 & 4.03 & 1.06 & 1.23 & $\begin{array}{ll}193.9 & 651.3 \\
\end{array}$ \\
\hline
\end{tabular}


Table 6. Pod length, pod diameter, pod weight, number of pods/plant and total pod yield/fed as affected by the interaction between compost rates and foliar spraying by some biostimulant substances during 2016 and 2017 seasons.

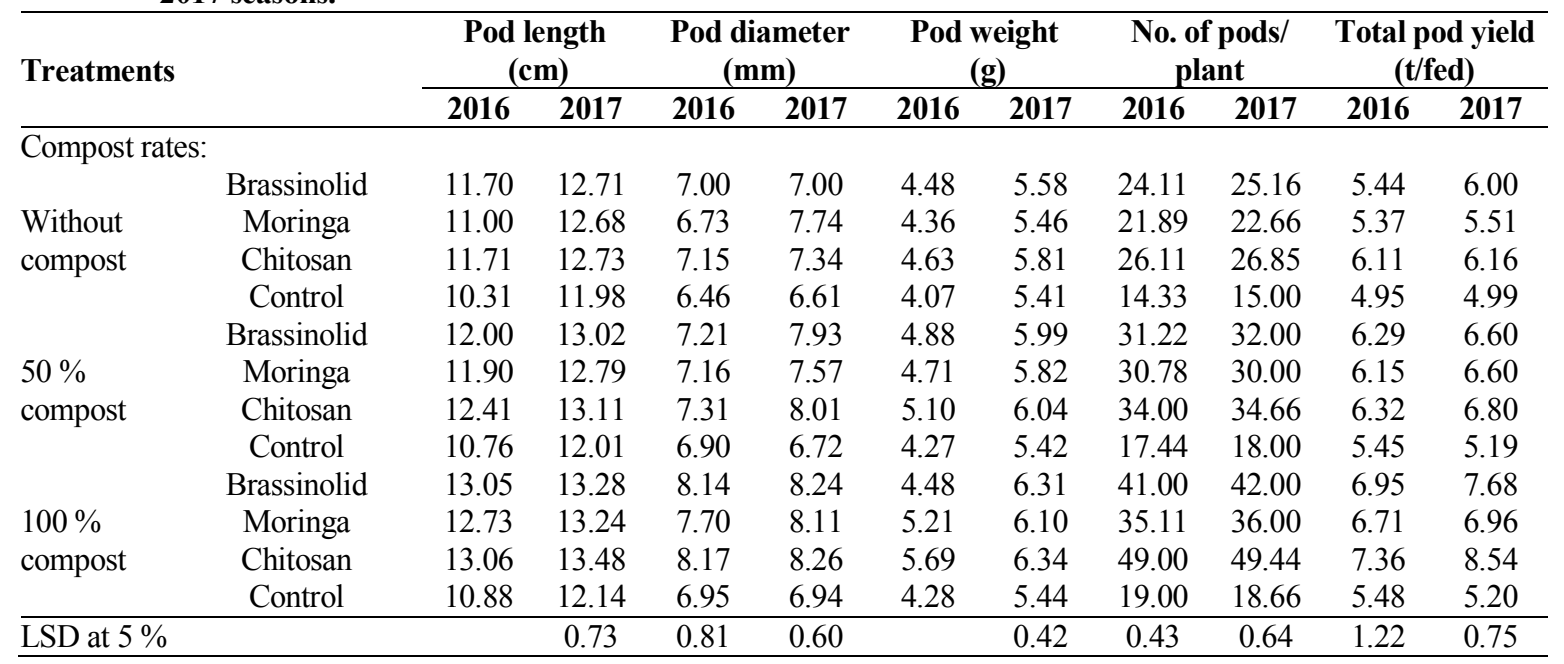

Table 7. Total soluble solids (TSS), crude protein (CP) and crude fiber (CF) percentages in snap bean podsas affected by the interaction between compost rates and foliar spraying with some biostimulant substances during 2016 and 2017 seasons.

\begin{tabular}{lccccccc}
\hline \multirow{2}{*}{ Treatments } & & \multicolumn{2}{c}{ TSS (\%) } & \multicolumn{2}{c}{ CP (\%) } & \multicolumn{2}{c}{ CF (\%) } \\
\cline { 3 - 7 } Compost rates: & & $\mathbf{2 0 1 6}$ & $\mathbf{2 0 1 7}$ & $\mathbf{2 0 1 6}$ & $\mathbf{2 0 1 7}$ & $\mathbf{2 0 1 6}$ & $\mathbf{2 0 1 7}$ \\
\cline { 3 - 7 } Without & & & & & & & \\
compost & Brassinolid & 6.33 & 6.66 & 20.93 & 23.21 & 7.73 & 8.22 \\
& Moringa & 6.33 & 6.66 & 20.31 & 23.00 & 7.82 & 8.45 \\
& Chitosan & 6.66 & 7.66 & 20.93 & 24.53 & 7.67 & 8.03 \\
$50 \%$ & Control & 5.66 & 5.66 & 19.37 & 20.06 & 8.96 & 10.02 \\
compost & Brassinolid & 6.66 & 7.33 & 21.25 & 24.75 & 7.18 & 7.45 \\
& Moringa & 6.66 & 7.33 & 21.04 & 24.71 & 7.38 & 8.03 \\
& Chitosan & 7.00 & 7.66 & 21.56 & 24.81 & 6.42 & 6.54 \\
$100 \%$ & Control & 6.00 & 7.00 & 20.00 & 20.15 & 8.58 & 9.71 \\
compost & Brassinolid & 8.32 & 8.65 & 21.87 & 24.88 & 6.13 & 8.15 \\
& Moringa & 7.00 & 8.00 & 21.87 & 24.87 & 6.44 & 8.00 \\
\hline LSD at 5 \% & Chitosan & 8.34 & 8.67 & 22.81 & 24.89 & 6.00 & 7.12 \\
\hline
\end{tabular}

\section{CONCLUSION}

It can be concluded that organic fertilizing snap bean plants with 4 tons compost/fed and foliar spraying three times, after 10 days from sowing and repeated each 10 days interval with chitosan at the rate of $200 \mathrm{ppm}$ in order to obtain high growth, yield and its components as well as quality of snap bean (Contender cultivar) in Damietta Governorate, Egypt under the environmental conditions .

\section{REFERENCES}

A.O.A.C. (2007). Official Methods of Analysis. $18^{\text {th }}$ Ed. Association of Official Analytical Chemists, Inc., Gaithersburg, MD, Method 04.

Abou El-Hassan, S.; Mona Abd Elwanis and M.Z. ElShinawy (2017). Application of compost and vermicompost as substitutes for mineral fertilizers to produce green beans. Egypt. J. Hort., 44(2): 155-163.

Abu-Muriefah, Sharifa S. (2013). Effect of chitosan on common bean (Phaseolus vulgaris L.) plants grown under water stress conditions. Intern. Res. J. of Agric. Sci. and Soil Sci., 3(6): 192-199.
Bucagu, C.; B. Ufitinema; D. Umutoniwabo; F. Niyitanga and A. Karangwa (2017). Effect of sheep manure and phosphorus fertilizer on productivity of snap bean (Phaseolus vulgaris L.) in Northern Rwanda. J. of Agric. and Ecol. Res. Intern., 12(1): 1-9.

Changa, R. X.; F.C. Michel-Jr; J.J. Gana; Q. Wangb; Z.Z. Wanga and Y.M. Lia (2017). Effect of single and combined herbicides in compost on growth of sensitive crops: green bean, cucumber, and tomato. Compost Sci. \& Utilization, 25(1): 23-30.

Chavan, B.L.; M.M. Vedpathak and B.R. Pirgonde (2015). Effects of organic and chemical fertilizers on cluster bean (Cyamopsis tetragonolobus). European J. of Exp. Bio., 5(1): 34-38.

El-Bassiony, A.M.; A.A. Ghoname; M.E. El-Awadi; Z.F. Fawzy and N. Gruda (2012). Ameliorative effects of brassinosteroids on growth and productivity of snap beans grown under high temperature. Gesunde Pflanzen, 64(4): 175-182. 
Emongor, V.E. (2015). Effects of moringa (Moringa oleifera) leaf extract on growth, yield and yield components of snap beans (Phaseolus vulgaris). British J. of App. Sci. \& Tech., 6(2): 114-122.

Fouda, K F.; A.M. El-Ghamry; Z.M. El-Sirafy and I.H.A. Klwet (2017). Integrated effect of fertilizers on beans cultivated in alluvial soil. Egypt. J. Soil Sci., 57(3): 303-312.

Gomez, K.A. and A.A. Gomez (1984). Statistical Procedures for Agricultural Research. 2nd Edn., Jhon Wiley and Sons Inc., New York, pp: 95-109.

Gregory, L.E. and N.B. Mandava (1982). The activity and interaction of brassinolide and gibberellic acid in mungbean (Phaseolus aureus) epicotyls. Physiol. of Plant, 54: 239-43.

Hesse, P.R. (1971). A text book of Soil Chemical Analysis. John. Murray (Publish), London, Great Britain.

Islam, M.A.; A.N. Boyce; M. Rahman; M.S. Azirun and M. Aqeel Ashraf (2016). Effects of organic fertilizers on the growth and yield of bush bean, winged bean and yard long bean. Brazilian Arch. Biol. Technol., 59(1): 1-9.

Kalinich, J.F.; N.V. Mandava and J.A. Todhunter (1985). Relationship of nucleic acid metabolism to brassinolide induced responses in beans. J. of Plant Physiol., 120: 207-14.

Koller, H.R. (1972). Leaf area - leaf weight relationship in the soybean canopy. Crop Sci., 12:180-183.

Marschner, H. (2012). Mineral nutrition of higher plants. $3^{\text {rd }}$ Ed. Academic Press is an imprinted of Elsevier.

Matwa, D.; K.P. Rao; J.S. Dhewa and R. Rajveer (2017). Effect of plant growth regulators (PGRs) and micronutrients on flowering and yield parameters of green gram (Vigna radiate L.). Int. J. Curr. Microbiol. App. Sci., 6(4): 2350-2356.
Rady, M.M.; W.M. Semida; K.A. Hemida and M.T. Abdelhamid (2016). The effect of compost on growth and yield of Phaseolus vulgaris plants grown under saline soil. Intern. J. Recycl. Org. Waste Agric., 5: 311-321.

Sairam, P.K. (1994). Effect of homo-brassinolide application on plant metabolism and grain yield under irrigated and moisture stress conditions of two wheat varieties. Plant Growth Reg., 14: 173-81.

Shahzad, U.; M.A. Khan; M.J. Jaskani; I.A. Khan and S.S. Korban (2013). Genetic diversity and population structure of Moringa oleifera. Cons. Gen., 14: 1161-1172.

Sheikha, S.A. and F.M. Al-Malki (2011). Growth and chlorophyll responses of bean plants to chitosan applications. European J. of Sci. Res., 50(1): 124134.

Snedecor, G. W. and W. G. Cochran (1980). Statistical methods. $7^{\text {th }}$ edition, Iowa State University Press, Ames, Iowa.

Thiyageshwari, S.; P. Gayathri; R. Krishnamoorthy; R. Anandham and D. Paul (2018). Exploration of rice husk compost as an alternate organic manure to enhance the productivity of blackgram in Typic Haplustalf and Typic Rhodustalf. Intern. J. Environ. Res. Public Health, 15: 1-14.

Zaki, Safinaz S. and M.M. Rady (2015). Moringa oleifera leaf extract improves growth, physiochemical attributes, antioxidant defence system and yields of salt-stressed Phaseolus vulgaris L. plants. Intern. J. of Chem. Tech. Res., 8(11): 120-134.

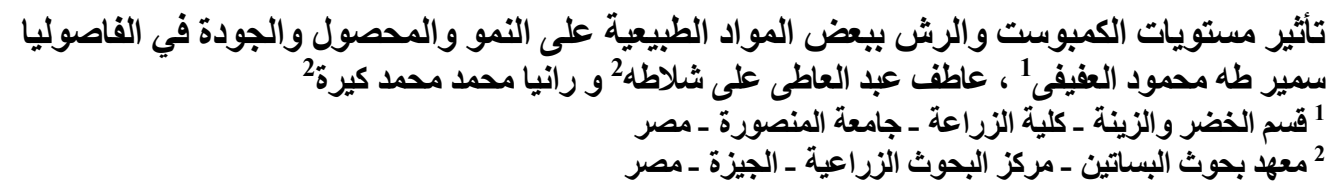

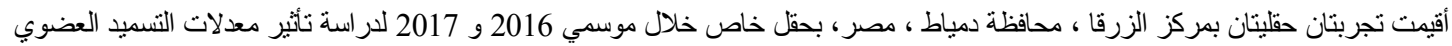

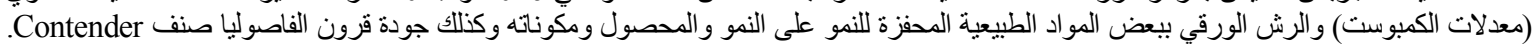

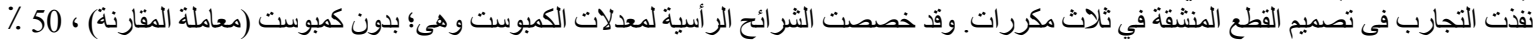

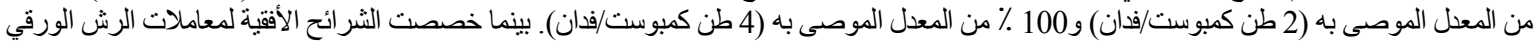

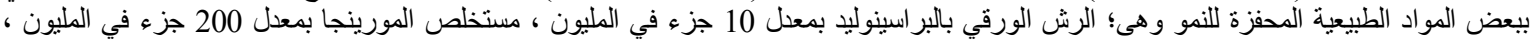

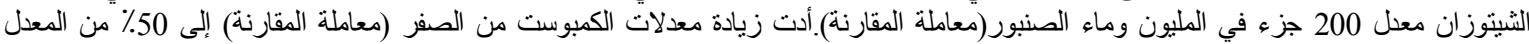

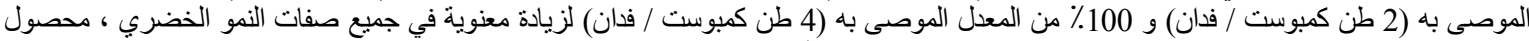

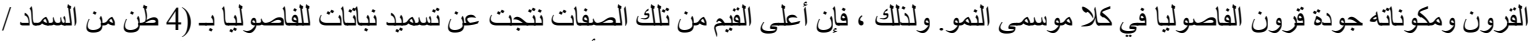

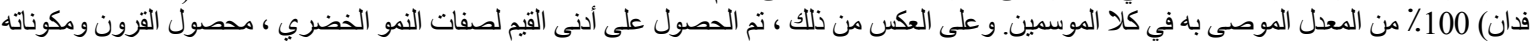

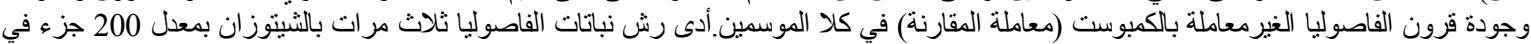

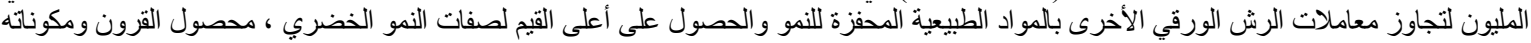

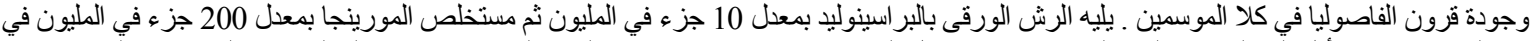

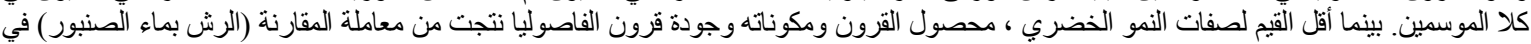

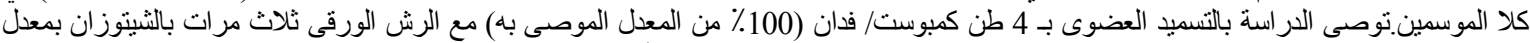

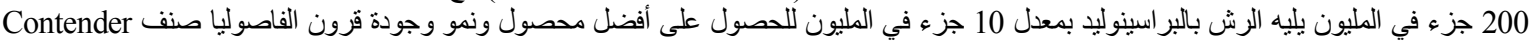

